\title{
Cloning Polymerase Chain Reaction (PCR) Products: TA Cloning
}

\author{
Michael R. Green and Joseph Sambrook
}

The nontemplate-dependent terminal transferase activity inherent in nonproofreading DNA polymerases such as Taq provides a highly efficient method to clone PCR products. The enzyme adds a single, unpaired residue-preferentially an adenosyl residue — to each $3^{\prime}$ end of a double-stranded amplified product. The unpaired terminal (A) residues can pair with a linear T vector that carries an unpaired 3'thymidyl residue at each end. The two chief advantages of TA cloning are speed and lack of reliance on restriction enzymes. The major disadvantage is an inability to clone directionally. For this reason, it is important to pick and analyze several transformed clones when a particular orientation of the amplified fragment is required.

\section{MATERIALS}

It is essential that you consult the appropriate Material Safety Data Sheets and your institution's Environmental Health and Safety Office for proper handling of equipment and hazardous materials used in this protocol.

RECIPES: Please see the end of this protocol for recipes indicated by $<R>$. Additional recipes can be found online at http://cshprotocols.cshlp.org/site/recipes.

Reagents

Agarose gels (and other reagents and equipment as required) (see Step 5)

$\operatorname{ATP}(10 \mathrm{~mm})$

Omit ATP from the ligation reaction in Step 1 if the ligation buffer contains ATP.

Bacteriophage T4 DNA ligase and buffer

See Introduction: Ligation and Ligases (Green and Sambrook 2019a). Some commercial ligase buffers contain ATP; when using such buffers, addition of ATP is not required.

$\mathrm{SOB}<\mathrm{R}>$, SOC $<\mathrm{R}>$, or $\mathrm{LB}<\mathrm{R}>$ agar plates containing the appropriate antibiotic

If blue/white screening is to be used, the plates should also contain X-Gal and IPTG (see Protocol: Screening Bacterial Colonies Using X-Gal and IPTG: $\boldsymbol{\alpha}$-Complementation [Green and Sambrook 2019b]).

Target DNA (25 ng/mL), amplified by PCR catalyzed by a nonproofreading thermostable DNA polymerase (e.g., Taq)

Typically, only $\sim 30 \%$ of the amplified products will carry an unpaired 3 -adenosyl residue. To maximize the efficiency of Taq-catalyzed addition of an unpaired A residue use primers carrying either a 5'-G residue or a 5'-A residue (Magnuson et al. 1996). The efficiency of the nontemplated addition reaction can be improved by programming a 10-min incubation at $72^{\circ} \mathrm{C}$ at the end of the $P C R$ amplification cycles.

Before cloning, check the size of an aliquot of the PCR product by gel electrophoresis. When the PCR generates more than one or two bands of amplified DNA, purify the target fragment by electrophoresis through low-melting/ gelling-temperature agarose. If not purified by gel electrophoresis, PCR-amplified DNA may be prepared for ligation by extracting the PCR with phenol:chloroform and precipitating the amplified DNA with ethanol.

From the Molecular Cloning collection, edited by Michael R. Green and Joseph Sambrook.

(C) 2021 Cold Spring Harbor Laboratory Press

Cite this protocol as Cold Spring Harb Protoc; doi:10.1101/pdb.prot101303 
However, many researchers will prefer to use a commercial cleanup kit, such as Wizard SV Gel and PCR Clean-Up System (Promega), PureLink PCR purification kit (Life Technologies), Milllipore Ultrafree spin columns, or QIAquik $P C R$ purification kit (QIAGEN). Some researchers recommend using the PCR products within a day or two of synthesis in insurance against loss of the protruding A-residue. Both T vectors and target DNAs tend to lose their unpaired $3^{\prime}$-residues during prolonged storage at $4^{\circ} \mathrm{C}$ and when frozen and thawed many times.

T vector

For synthesis of T vectors, see Protocol: Cloning Polymerase Chain Reaction (PCR) Products: Making T Vectors (Green and Sambrook 2021).

Ready-made T-vectors can be purchased from many commercial suppliers as components of cloning kits (e.g., $p C R$-Script [SK+] from Stratagene; $p C R I I$ in the TA Cloning kit from Life Technologies; pGEM-T from Promega) (Hengen 1995).

Transformation-competent E. coli cells (and other reagents and equipment for transforming E. coli as required, described in Protocol: The Hanahan Method for Preparation and Transformation of Competent Escherichia coli: High-Efficiency Transformation [Green and Sambrook 2018] and Protocol: The Inoue Method for Preparation and Transformation of Competent Escherichia coli: "Ultracompetent" Cells [Green and Sambrook 2020a])

Transformation-competent E. coli cells can be bought commercially or prepared as described in Protocol: The Hanahan Method for Preparation and Transformation of Competent Escherichia coli: High-Efficiency Transformation (Green and Sambrook 2018), Protocol: The Inoue Method for Preparation and Transformation of Competent Escherichia coli: "Ultracompetent" Cells (Green and Sambrook 2020a), Protocol: Easy Transformation of Escherichia coli: Nanoparticle-Mediated Transformation (Green and Sambrook 2019C), and Protocol: Transformation of Escherichia coli by Electroporation (Green and Sambrook 2020b).

Equipment

Incubator $\left(37^{\circ} \mathrm{C}\right)$

Water bath (preset to $14^{\circ} \mathrm{C}$ )

For more information on this method, see Clark (1988); Holton and Graham (1991); Marchuk et al. (1991); Trower and Elgar (1994); Zhou and Gomez-Sanchez (2000).

1. In a microcentrifuge tube, set up a ligation reaction.

$\begin{array}{ll}\text { Amplified target DNA }(25 \mathrm{ng} / \mu \mathrm{L}) & 1 \mu \mathrm{L} \\ \text { T-tailed plasmid }(75 \mathrm{ng} / \mu \mathrm{L}) & 1 \mu \mathrm{L} \\ \text { Ligation buffer }(10 \times) & 1 \mu \mathrm{L} \\ \text { Bacteriophage T4 DNA ligase } & 3 \mathrm{U} \\ \mathrm{H}_{2} \mathrm{O} & \text { to } 10 \mu \mathrm{L}\end{array}$

The optimal molar ratio of vector:amplified DNA in the ligation mixture is 3:1. The amounts of the two DNAs suggested for the ligation reaction (above) assume that the vector and amplified DNA are of equal size. This will rarely be the case. When the size of the target DNA is known, the relative amounts of the two types of DNA included in the ligation reaction should be altered to achieve a molar ratio of 3:1 (vector:amplified DNA).

If necessary, add ATP to a final concentration of $1 \mathrm{~mm}$. Set up a control reaction that contains all the reagents listed above except the amplified target DNA.

2. Incubate the ligation mixtures for $4 \mathrm{~h}$ at $14^{\circ} \mathrm{C}$.

3. Dilute $5 \mu \mathrm{L}$ of each of the two ligation mixtures with $10 \mu \mathrm{L}$ of $\mathrm{H}_{2} \mathrm{O}$ and transform a suitable strain of competent E. coli to antibiotic resistance as described in Protocol: The Hanahan Method for Preparation and Transformation of Competent Escherichia coli: High-Efficiency Transformation (Green and Sambrook 2018), Protocol: The Inoue Method for Preparation and Transformation of Competent Escherichia coli: "Ultracompetent" Cells (Green and Sambrook 2020a), Protocol: Easy Transformation of Escherichia coli: Nanoparticle-Mediated Transformation (Green and Sambrook 2019c), and Protocol: Transformation of Escherichia coli by Electroporation (Green and Sambrook 2020b). Plate the transformed cultures on media containing the 
M.R. Green and J. Sambrook

appropriate antibiotic and, depending on the genotype of the host and vector, IPTG and X-Gal (see Protocol: Screening Bacterial Colonies Using X-Gal and IPTG: $\alpha$-Complementation [Green and Sambrook 2019b]).

4. Calculate the number of colonies obtained from each of the ligation mixtures. If the plasmid is equipped for blue/white screening, pick a number of white colonies obtained by transformation with the ligation reaction containing the target DNA. In different experiments, the ratio of blue: white colonies can vary between 1:5 and 2:1.

5. Confirm the presence of the amplified fragment by isolating the recombinant plasmid DNAs and digesting them with the appropriate restriction enzymes. Fractionate the restricted DNA by electrophoresis through an agarose gel using appropriate DNA size markers.

\section{RELATED INFORMATION}

TA cloning is universal in the sense that any $\mathrm{T}$ vector can be used to clone any A-tailed segment of DNA. PCR may be the method most commonly used to generate A-tailed DNA molecules, but it is not the only way. DNA fragments with blunt ends or 5'-protruding termini can be equipped with $3^{\prime}$ adenosyl tails in a reaction containing all four dNTPs that is catalyzed by Taq polymerase. The enzyme first polishes the termini and then adds the supernumerary $3^{\prime}-\mathrm{A}$ residues. An extra step is required to attach unpaired $3^{\prime}$-adenosyl residues to DNA with protruding $3^{\prime}$ tails. The termini are removed in a reaction catalyzed by T4 DNA polymerase and containing all four dNTPs. The blunt-ended molecules can then be equipped with $3^{\prime}$-A tails, as described above.

\section{LB (Luria-Bertani) Liquid Medium}

\begin{tabular}{lr} 
Reagent & Amount to add \\
\hline $\mathrm{H}_{2} \mathrm{O}$ & $950 \mathrm{~mL}$ \\
Tryptone & $10 \mathrm{~g}$ \\
$\mathrm{NaCl}$ & $10 \mathrm{~g}$ \\
Yeast extract & $5 \mathrm{~g}$
\end{tabular}

Combine the reagents and shake until the solutes have dissolved. Adjust the $\mathrm{pH}$ to 7.0 with $5 \mathrm{~N} \mathrm{NaOH}(\sim 0.2 \mathrm{~mL})$. Adjust the final volume of the solution to $1 \mathrm{~L}$ with $\mathrm{H}_{2} \mathrm{O}$. Sterilize by autoclaving for $20 \mathrm{~min}$ at $15 \mathrm{psi}\left(1.05 \mathrm{~kg} / \mathrm{cm}^{2}\right)$ on liquid cycle.

For solid medium, see the recipe entitled "Media containing agar or agarose."

\section{Media Containing Agar or Agarose}

Prepare liquid media according to the recipe given. Just before autoclaving, add one of the following:

Bacto agar (for plates)

Bacto agar (for top agar)

Agarose (for plates)

Agarose (for top agarose)
$15 \mathrm{~g} / \mathrm{L}$

$7 \mathrm{~g} / \mathrm{L}$

$15 \mathrm{~g} / \mathrm{L}$

$7 \mathrm{~g} / \mathrm{L}$

Sterilize by autoclaving for $20 \mathrm{~min}$ at $15 \mathrm{psi}\left(1.05 \mathrm{~kg} / \mathrm{cm}^{2}\right)$ on liquid cycle. When the medium is removed from the autoclave, swirl it gently to distribute the melted agar or agarose evenly throughout the solution. Be careful! The fluid may be superheated and 
may boil over when swirled. Before adding thermolabile substances (e.g., antibiotics), allow the medium to cool to $50^{\circ} \mathrm{C}-60^{\circ} \mathrm{C}$, and mix the medium by swirling to avoid producing air bubbles.

Before pouring the plates, set up a color code (e.g., two red stripes for LB-ampicillin plates; one black stripe for LB plates, etc.), and mark the edges of the plates with the appropriate colored markers. Pour plates directly from the flask; allow $\sim 30-35 \mathrm{~mL}$ of medium per $90-\mathrm{mm}$ plate. To remove bubbles from the medium in the plate, flame the surface of the medium with a Bunsen burner before the agar or agarose hardens. When the medium has hardened completely, invert the plates and store them at $4^{\circ} \mathrm{C}$ until needed.

The plates should be removed from storage $1-2 \mathrm{~h}$ before they are used. If the plates are fresh, they will "sweat" when incubated at $37^{\circ} \mathrm{C}$. When this condensation drops on the agar/agarose surface, it allows bacterial colonies or bacteriophage plaques to spread and increases the chances of cross-contamination. This problem can be avoided by wiping off the condensation from the lids of the plates and then incubating the plates for several hours at $37^{\circ} \mathrm{C}$ in an inverted position before they are used. Alternatively, remove the liquid by shaking the lid with a single, quick motion. To minimize the possibility of contamination, hold the open plate in an inverted position while removing the liquid from the lid.

\section{SOB Medium}

Per liter: To $950 \mathrm{~mL}$ of deionized $\mathrm{H}_{2} \mathrm{O}$, add:

Tryptone

Shake until the solutes have dissolved. Add $10 \mathrm{~mL}$ of a $250 \mathrm{~mm}$ solution of $\mathrm{KCl}$. (This solution is made by dissolving $1.86 \mathrm{~g}$ of $\mathrm{KCl}$ in $100 \mathrm{~mL}$ of deionized $\mathrm{H}_{2} \mathrm{O}$.) Adjust the $\mathrm{pH}$ of the medium to 7.0 with $5 \mathrm{~N} \mathrm{NaOH}(\sim 0.2 \mathrm{~mL})$. Adjust the volume of the solution to $1 \mathrm{~L}$ with deionized $\mathrm{H}_{2} \mathrm{O}$. Sterilize by autoclaving for $20 \mathrm{~min}$ at $15 \mathrm{psi}\left(1.05 \mathrm{~kg} / \mathrm{cm}^{2}\right)$ on liquid cycle. Just before use, add $5 \mathrm{~mL}$ of a sterile solution of $2 \mathrm{M} \mathrm{MgCl}_{2}$. (This solution is made by dissolving $19 \mathrm{~g}$ of $\mathrm{MgCl}_{2}$ in $90 \mathrm{~mL}$ of deionized $\mathrm{H}_{2} \mathrm{O}$. Adjust the volume of the solution to $100 \mathrm{~mL}$ with deionized $\mathrm{H}_{2} \mathrm{O}$ and sterilize by autoclaving for $20 \mathrm{~min}$ at 15 psi $\left[1.05 \mathrm{~kg} / \mathrm{cm}^{2}\right]$ on liquid cycle.)

For solid medium, please see the recipe entitled "Media containing agar or agarose." $<\mathrm{R}>$

\section{SOC Medium}

Per liter: To $950 \mathrm{~mL}$ of deionized $\mathrm{H}_{2} \mathrm{O}$, add:

Tryptone

SOC medium is identical to SOB medium, except that it contains $20 \mathrm{~mm}$ glucose. To prepare $\mathrm{SOB}$ medium, combine the above ingredients and shake until the solutes have dissolved. Add $10 \mathrm{~mL}$ of a $250 \mathrm{~mm}$ solution of $\mathrm{KCl}$. (This solution is made by dissolving $1.86 \mathrm{~g}$ of $\mathrm{KCl}$ in $100 \mathrm{~mL}$ of deionized $\mathrm{H}_{2} \mathrm{O}$.) Adjust the $\mathrm{pH}$ of the medium to 7.0 with $5 \mathrm{~N}$ $\mathrm{NaOH}(\sim 0.2 \mathrm{~mL})$. Adjust the volume of the solution to $1 \mathrm{~L}$ with deionized $\mathrm{H}_{2} \mathrm{O}$. Sterilize by autoclaving for $20 \mathrm{~min}$ at $15 \mathrm{psi}\left(1.05 \mathrm{~kg} / \mathrm{cm}^{2}\right)$ on liquid cycle. Just before use, add $5 \mathrm{~mL}$ of a sterile solution of $2 \mathrm{M} \mathrm{MgCl}_{2}$. (This solution is made by dissolving $19 \mathrm{~g}^{\circ} \mathrm{MgCl}_{2}$ 
M.R. Green and J. Sambrook

in $90 \mathrm{~mL}$ of deionized $\mathrm{H}_{2} \mathrm{O}$. Adjust the volume of the solution to $100 \mathrm{~mL}$ with deionized $\mathrm{H}_{2} \mathrm{O}$ and sterilize by autoclaving for $20 \mathrm{~min}$ at $15 \mathrm{psi}\left[1.05 \mathrm{~kg} / \mathrm{cm}^{2}\right]$ on liquid cycle.)

After the SOB medium has been autoclaved, allow it to cool to $60^{\circ} \mathrm{C}$ or less. Add $20 \mathrm{~mL}$ of a sterile $1 \mathrm{M}$ solution of glucose. (This solution is made by dissolving $18 \mathrm{~g}$ of glucose in $90 \mathrm{~mL}$ of deionized $\mathrm{H}_{2} \mathrm{O}$. After the sugar has dissolved, adjust the volume of the solution to $100 \mathrm{~mL}$ with deionized $\mathrm{H}_{2} \mathrm{O}$ and sterilize by passing it through a $0.22-\mu \mathrm{m}$ filter.)

\section{REFERENCES}

Clark JM. 1988. Novel non-templated nucleotide addition reactions catalyzed by procaryotic and eucaryotic DNA polymerases. Nucleic Acids Res 16: $9677-9686$.

Green MR, Sambrook J. 2018. The Hanahan method for preparation and transformation of competent Escherichia coli: High-efficiency transformation. Cold Spring Harb Protoc doi: 10.1101/pdb.prot101188.

Green MR, Sambrook J. 2019a. Ligation and ligases. Cold Spring Harb Protoc doi: $10.1101 /$ pdb.top101352.

Green MR, Sambrook J. 2019b. Screening bacterial colonies using X-Gal and IPTG: $\alpha$-Complementation. Cold Spring Harb Protoc doi: 10.1101/pdb. prot101329.

Green MR, Sambrook J. 2019c. Easy transformation of Escherichia coli: Nanoparticle-mediated transformation. Cold Spring Harb Protoc doi: 10.1101/pdb.prot101204.

Green MR, Sambrook J. 2020a. The Inoue method for preparation and transformation of competent Escherichia coli: "Ultracompetent" cells. Cold Spring Harb Protoc doi: 10.1101/pdb.prot101196.

- Green MR, Sambrook J. 2020b. Transformation of Escherichia coli by electroporation. Cold Spring Harb Protoc doi: 10.1101/pdb.prot101220.
Green MR, Sambrook J. 2021. Cloning polymerase chain reaction (PCR) products: Making T vectors. Cold Spring Harb Protoc doi: 10.1101/pdb. prot101295.

Hengen PN. 1995. Methods and reagents. Cloning PCR products using Tvectors. Trends Biochem Sci 20: 85-86.

Holton TA, Graham MW. 1991. A simple and efficient method for direct cloning of PCR products using ddT-tailed vectors. Nucleic Acids Res 19: 1156.

Magnuson VL, Ally DS, Nylund SJ, Karanjawala ZE, Rayman JB, Knap JI, Lowe AL, Ghosh S, Collins FS. 1996. Substrate nucleotide-determined non-templated addition of adenine by Taq DNA polymerase: Implications for PCR-based genotyping and cloning. Biotechniques 21: 700-709.

Marchuk D, Drumm M, Saulino A, Collins FS. 1991. Construction of Tvectors, a rapid and general system for direct cloning of unmodified PCR products. Nucleic Acids Res 19: 1154.

Trower MK, Elgar GS. 1994. PCR cloning using T-vectors. Methods Mol Biol 31: 19-33.

Zhou MY, Gomez-Sanchez CE. 2000. Universal TA cloning. Curr Issues Mol Biol 2: 1-7. 


\section{Cloning Polymerase Chain Reaction (PCR) Products: TA Cloning}

Michael R. Green and Joseph Sambrook

Cold Spring Harb Protoc; doi: 10.1101/pdb.prot101303

\begin{tabular}{|c|c|}
\hline $\begin{array}{r}\text { Email Alerting } \\
\text { Service }\end{array}$ & Receive free email alerts when new articles cite this article - click here. \\
\hline $\begin{array}{r}\text { Subject } \\
\text { Categories }\end{array}$ & $\begin{array}{l}\text { Browse articles on similar topics from Cold Spring Harbor Protocols. } \\
\text { Cloning of PCR Products (20 articles) } \\
\text { Molecular Biology, general (1293 articles) } \\
\text { Plasmids (154 articles) } \\
\text { Polymerase Chain Reaction (PCR) (139 articles) } \\
\text { Polymerase Chain Reaction (PCR), general (184 articles) } \\
\text { Vectors (141 articles) }\end{array}$ \\
\hline
\end{tabular}

